\title{
PENERAPAN METODE STRUKTUR ANALITIK SINTETIK UNTUK MENINGKATKAN KEMAMPUAN MEMBACA PERMULAAN SISWA PADA KELAS II SDN 11 KENDARI
}

\author{
Rahmania Taipo ${ }^{1)}$, Mansyur, M. ${ }^{2)}$ \\ 1) SDN 11 Kendari, Kendari, Indonesia \\ ${ }^{2)}$ Jurusan PGSD, Universitas Halu Oleo, Kendari, Indonesia \\ email: rahmaniataipo24@gmail.com
}

\begin{abstract}
Abstrak: Penelitian ini bertujuan untuk mengetahui penerapan metode struktur analitik sintetik dalam meningkatkan kemampuan membaca permulaan siswa kelas II SDN 11 Kendari. Jenis penelitian ini adalah penelitian tindakan kelas. Subjek penelitian ini adalah siswa kelas II SDN 11 Kendari sebanyak 24 siswa yang terdiri 12 siswa laki- laki dan 12 siswa perempuan. Teknik pengumpulan data dilakukan dengan tes, observasi, dan dokumentasi. Data kuantitatif dianalisis dengan menggunakan statistik deskriptif dan data kualitatif dengan menggunakan model alur. Indikator keberhasilan siswa ditandai dengan meningkatnya kemampuan membaca permulaan siswa dengan nilai rata- rata 70 dan ketuntasan siswa mencapai $80 \%$. Berdasarkan hasil penelitian diperoleh kesimpulan bahwa pembelajaran menggunakan metode struktur snalitik sintetik dapat meningkatkan kemampuan membaca permulaan siswa kelas II SDN 11 Kendari. Meningkatnya kemampuan membaca permulaan siswa ditandai dengan meningkatnya keaktifan siswa dalam mengikuti pembelajaran. Hasil nilai rata-rata kemampuan membaca permulaan siswa pada kondisi awal sebesar $41,67 \%$. Nilai rata- rata pada siklus I meningkat $12,5 \%$ (kondisi awal $41,67 \%$ menjadi $54,17 \%$ ) dan pada siklus II meningkat 29,16\% (kondisi awal 41,67\% menjadi 83,33\%)
\end{abstract}

Kata kunci: membaca permulaan; metode struktur analitik sintetik (SAS)

\section{THE APPLICATION OF SYNTHETIC ANALYTICAL STRUCTURES TO IMPROVE READING ABILITY OF STUDENTS IN CLASS II SDN 11 KENDARI}

\begin{abstract}
This research aims to determine the application of synthetic analytical structure methods to improve the ability to read the beginning of class II SDN 11 Kendari. This type of research is classroom action research. The subjects of this study were class II SDN 11 Kendari as many as 24 students consisting of 12 male students and 12 female students. Data collection techniques are carried out by tests, observations, and documentation. Quantitative data were analyzed using descriptive statistics and qualitative data using the groove model. The indicator of student success is characterized by an increase in the ability to read the beginning of students with an average score of 70 and the completeness of students reaches $80 \%$. Based on the results of the study, it can be concluded that learning using the synthetic snalytic structure method can improve the ability to read the beginning of class II SDN 11 Kendari. Increasing the ability to read the beginning of students is marked by increased activity of students in participating in learning. The results of the average value of students' initial reading ability in the initial conditions were $41.67 \%$. The average value in the first cycle increased by $12.5 \%$ (initial conditions $41.67 \%$ to $54.17 \%$ ) and in the second cycle increased by $29.16 \%$ (initial conditions $41.67 \%$ to $83.33 \%$ ).
\end{abstract}

Keywords: preliminary reading; synthetic analytical structure (SAS) method 


\section{Pendahuluan}

Bahasa adalah sarana untuk memperoleh ilmu dan sekaligus bagian dari budaya, serta sarana berkomunikasi. Siswa di kelas I SD sudah di ajarkan membaca karena membaca memegang peranan penting dalam meningkatkan kemampuan dasar disemua bidang ilmu, yang merupakan tonggak dalam mengembangkan intelek serta potensi yang dimiliki anak. Membaca merupakan bagian dari 4 aspek keterampilan berbahasa yang harus dimiliki setiap manusia. Keterampilan ini tidak dapat dipisahkan dalam kehidupan manusia. Pada dasarnya membaca merupakan kemampuan menghubung-kan antara bahasa lisan dengan tulisan, dalam kaitannya dengan kemampuan membaca permulaan, keterampilan penguasaan kosakata sangatlah penting bagi anak (Aulina, 2012, p.133).

Kemampuan membaca merupakan dasar untuk menguasai berbagai bidang studi. Lerner dalam Mayangsari (2014, p.63) anak harus belajar membaca agar ia dapat membaca untuk belajar. Melalui kegiatan membaca permulaan ini guru dapat memberi contoh membaca, dengan kecepatan, irama, dan suara yang tepat (Mile, 2016, p.258). Keterampilan membaca merupakan keterampilan dasar yang sangat penting bagi kehidupan manusia (Kurniawan, 2016, p.149). Pemerolehan bahasa anak melibatkan dua keterampilan, yaitu kemampuan untuk menghasilkan tuturan secara spontan dan kemampuan memahami tuturan orang lain. Tujuan utama dari membaca permulaan adalah agar anak dapat mengenal tulisan sebagai lambang atau simbol bahasa sehingga anak-anak dapat menyuarakan tulisan tersebut (Dewi, 2015, p.2). Menurut Dardjowidjojo dalam Salamah (2015, p.74) pemerolehan bahasa didefinisikan sebagai proses penguasaan bahasa yang dilakukan oleh anak secara natural pada waktu dia belajar bahasa ibunya. Sedangkan menurut Richard dalam Salamah (2015, p.74) pemerolehan bahasa tersebut merupakan proses bawah sadar, atau proses mental yang mengarah pada kompetensi berbahasa dan penguasaan tata bahasa. Sedangkan Taylor, dalam (Salamah, 2015, p.74). berpendapat bahwa kajian terhadap pemerolehan bahas pada hakikatnya terdiri dari dua aspek, yaitu (i) bahasa apakah yang diperoleh anak, serta (ii) bagaimana anak memperoleh bahasa.

Kenyataannya banyak guru terjebak dalam tatanan konsep dan penerapan pembelajaran yang masih berupa konvensioanl atau tradisional sehingga mempengaruhi keterampilan membaca siswa utamanya membaca permulaan siswa kelas rendah menjadi sangat kurang. Hal ini terbukti dari dokument guru mengenai hasil belajar siswa dalam kemampuan membaca terdapat 10 siswa yang mancapai nilai KKM sedangkan 14 siswa mencapai nilai 40-60, sedangkan KKM pelajaran bahasa Indonesia di kelas II SDN 11 Kendari sebesar 70.

Berdasarkan hasil observasi yang dilakukan pada tanggal 9 Oktober 2018, dengan guru kelas II SDN 11 Kendari, Faktor yang menyebabkan rendahnya kemampuan membaca siswa kelas II karena disebabkan oleh beberapa hal, di antaranya adalah hasil ujian tengah semester dari $100 \%$ siswa hanya $40 \%$ yang memiliki kemampuan membaca yang maksimal. Hal ini disebabkan kurang nya metode yang diterapkan oleh guru dalam melakukan proses pembelajaran. Sehingga peneliti memberikan solusi dengan penerapan metode struktur analitik sintetik (SAS). Hal ini diharapkan guru dalam melaksanakan proses pembelajaran dapat menerapkan metode struktur analitik sintetik (SAS) tersebut sehingga kemampuan membaca permulaan siswa meningkat. Supriyadi dalam Sandi (2014, p.99) bahwa pengertian metode struktur analitik sintetik (SAS) adalah suatu pendekatan cerita disertai gambar yang didalamnya terkandung unsur analitik sintetik. Menurut Yeti Mulyati dalam Aisa (2014, p.30) dipilihnya metode SAS karena siswa mulai melafalkan huruf, suku kata, kata, dan kalimat sederhana dengan menggunakan vokal, lafal dan intonasi yang tepat. Selain itu, digunakannya media berupa kartu huruf, kartu suku kata, kartu kata dan kartu kalimat sederhana agar memungkinkan siswa dapat bermain dengan kartu tersebut kemudian membacanya. Dalam 
proses operasionalnya metode SAS mempunyai langkah-langkah berlandaskan operasional dengan urutan, struktural menampilkan keseluruhan, analitik melakukan proses penguraian, sintetik melakukan penggabungan kembali kepada bentuk struktural semula (Hidayah, 2016, p.86). Menurut Sumarni, dkk (2014, p.93) menjelaskan bahwa pengembangan pengetahuan berupa kiat-kiat, teknik-teknik, dan metode-metode sangat mendukung keberhasilan pembelajaran. Kiat-kiat merupakan usaha yang dapat membantu memperlancar proses pembelajaran. Teknik dan metode adalah suatu hal yang sangat mendukung dalam perencanaan penyusunan rencana pembelajaran dengan tujuan agar pelaksanaan lebih menarik dan menyenangkan. Struktural bahasa terdiri atas kalimat. Analitik berarti memisahkan, menceraikan, membagi, menguraikan, membongkar dan lainlain. Sintetik berarti menyatukan, menggabungkan, merangkai, menyusun. Setelah kita mengenal struktur, mengenal bagian secara analitik, selanjutnya kita sintesis untuk kembali mengenal struktur. Jadi usaha secara sintetik berarti kembali mengenal bentuk struktur. Metode Struktural Analitik Sintetik (SAS) dalam pembelajaran bahasan menekankan sekali hal-hal yang fungsional (Rudiyanto, 2014, p.4). Atas dasar itu, peneliti memilih metode SAS dan media pembelajaran di atas.

Berdasarkan hal tersebut di atas maka peneliti merasa tertarik untuk melakukan penelitian dengan judul "Penerapan Metode Struktur Analitik Sintetik untuk Meningkatkan Kemampuan Membaca Permulaan Siswa pada Tema Merawat Hewan dan Tumbuhan Kelas II SDN 11 Kendari”.

Adapun tujuan penelitian ini adalah untuk mengetahui Penerapan Metode Struktur Analitik Sintetik dalam Meningkatkan Kemampuan Membaca Permulaan Siswa pada Tema Merawat Hewan dan Tumbuhan Kelas II SDN 11 Kendari.

\section{Metode}

Penelitian ini termasuk dalam jenis penelitian Classroom Action Research (CAR) atau biasa disebut penelitian tindakan kelas (PTK) Penelitian ini merupakan penelitian yang pelaksanaannya dilakukan secara bersiklus. Setiap siklus dilakukan perencanaan, pelaksanaan, observasi, dan refleksi secara bertahap sampai pada target yang ditentukan dicapai. Heris Hendriana dan Afrilianto dalam Paizaluddin dkk (2014, p.8), mengemukakan bahwa penelitian tindakan kelas (PTK) merupakan suatu bentuk penelitian yang bersifat reflektif dengan melakukan tindakan tertentu agar dapat memperbaiki/ meningkatkan praktik pembelajaran di kelas secara lebih profesional.

Penelitian ini dilaksanakan di SD Negeri 11 Kendari yang beralamat di Jalan Bangau Kelurahan Puunggaloba, Kota Kendari. Penelitian ini dilaksanakan pada bulan 2 hari selasa 12 februari semester genap tahun ajaran 2018/2019.

Subjek penelitian ini adalah guru dan siswa kelas II SDN 11 Kendari dimana siswa kelas II berjumlah 24 orang. Jumlah siswa laki-laki sebanyak 12 orang dan jumlah siswa perempuan sebanyak 12 orang.

Faktor-faktor yang diteliti menggunakan Penerapan Metode struktur Analitik Sintetik (SAS) dalam mengukur kemampuan membaca permulaan siswa adalah sebagai berikut:

1. Faktor siswa: Melihat faktor yang mempengaruhi rendahnya kemampuan siswa dalam membaca permulaan, melihat bagaimana siswa mempelajari materi pembelajaran pada tema 6 Merawat Hewan dan Tumbuhan melalui tahapan metode pembelajaran SAS kemudian memperhatikan prestasi belajar siswa.

2. Faktor guru: Melihat bagaimana kemampuan guru dalam menguasai metode SAS dalam meningkatkan kemampuan membaca permulaan siswa. 
3. Faktor hasil belajar: Melihat hasil belajar 2017/2018 siswa rendah disebabkan oleh faktor guru yang mengajar masih konvensional sehingga peneliti memberikan metode struktur analitik sintetik (SAS).

Desain yang digunakan dalam penelitian ini adalah model Suharsimi Arikunto dalam Paizaluddin (2014, p.34-39) yang terdiri atas empat tahap, yaitu perencanaan, pelaksanaan, pengamatan dan refleksi.

Data dalam penelitian ini yaitu data kualitatif dan data kuantitatif. Data kualitatif diperoleh melalui observasi selama proses pembelajaran ketika guru menggunakan metode struktur analitik sintetik (SAS) dan data kuantitatif diperoleh dari hasil tes belajar siswa.

Sumber data dalam penelitian ini adalah siswa kelas II SDN 11 Kendari sebanyak 24 orang dan guru kelas II. Data penelitan ini diperoleh melalui observasi, dokumentasi dan tes. Metode ini digunakan untuk mencari data pelengkap agar lebih akurat. Analisis data dalam penelitian ini menggunakan deskriptif kualitatif, Sedangkan data kuantitatif dianalisis secara deskriptif kuantitatif.

Indikator kinerja adalah suatu kriteria yang dapat digunakan dalam melihat tingkat keberhasilan dari kegiatan penelitian tindakan kelas. Indikator dalam penelitian ini adalah sebagai berikut:

1. Hasil belajar siswa dikatakan berhasil apabila $80 \%$ mencapai KKM yang telah ditetapkan oleh sekolah yaitu sebesar 70 .

2. Penggunaan metode struktur analitik sintetik (SAS) dikatakan berhasil apabila dalam pelaksanaan skenario pembelajaran mencapai $80 \%$ dari keseluruhan skenario pembelajaran.

\section{Pembahasan}

Penelitian ini adalah penelitian tindakan kelas yang dilaksanakan dalam dua siklus tindakan. Setiap siklus terdiri atas empat kegiatan pokok yang dilakukan secara bertahap yaitu: (1) perencanaan, (2) pelaksanaan tindakan, (3) observasi dan evaluasi, (4) refleksi. Sebelum melaksanakan penelitian, dilakukan kegiatan berupa pengamatan hasil belajar membaca permulaan siswa.

Hasil pengamatan menunjukkan bahwa dari 24 siswa kelas II SDN 11 Kendari, 10 orang siswa $(41,67 \%)$ yang memperoleh nilai $\geq 70$ dan 14 orang siswa $(58,63 \%)$ memperoleh skor $\leq 70$. Hasil tersebut membuktikan bahwa kemampuan membaca permulaan siswa kelas II SDN 11 Kendari masih rendah. Hasil pengamatan tersebut dijadikan dasar agar dalam melakukan perbaikan pembelajaran untuk meningkatkan kemampuan membaca permulaan siswa kelas II SDN 11 Kendari.

Berdasarkan hasil observasi pada siklus I, guru dan siswa telah melakukan kegiatan pembelajaran yang sesuai dengan metode struktur analitik sintetik (SAS). Namun masih terdapat beberapa kekurangan yang dilakukan guru dan masalah yang dihadapi siswa dalam proses pembelajaran. Kekurangan yang dilakukan guru dalam proses pembelajaran adalah guru melaksanakan proses pembelajaran tidak secara sistematis dan tidak sesuai dengan metode struktur analitik sintetik (SAS).

Aktivitas mengajar guru pada penelitian ini diketahui melalui hasil observasi pada setiap siklus tindakan. Hasil observasi siklus I (satu) menunjukkan bahwa presentase terlaksana guru pada siklus I pertemuan I (pertama) adalah 13 dan pertemuan II (kedua) 14 sedangkan maksimum presentase terlaksana adalah 16. Melihat kekurangan yang masih ada serta hasil belajar siswa belum mencapai indikator keberhasilan yang telah ditetapkan, maka penelitian dilanjutkan pada tindkan siklus II (dua) dimana guru lebih mengaktifkan siswa dan membimbing siswa untuk bisa melakukan analisis dan sintetis terhadap struktur kalimat. Presentase terlaksana guru pada siklus II (dua) pertemuan I (pertama) adalah 15 dan 
pertemuan II (kedua) adalah 16 sedangkan presentase maksimum terlaksana adalah 16 maka presentase keberhasilan aktivitas mengajar guru pada siklus II telah berhasil dan sesuai dengan skenario pembelajaran dengan menggunakan metode struktur analitik sintetik (SAS).

Hasil observasi aktivitas belajar siswa siklus 1 menunjukkan bahwa siswa belum memahami materi pelajaran dengan baiksehingga berpengaruh pada presentase terlaksana aktivitas belajar siswa. Presentase terlaksana aktivitas belajar siswa pada pembelajaran siklus I (satu) pertemua I (pertama) adalah 10 dan pertemuan II (kedua) adalah 11. Hasil siklus II (dua) menunjukkan bahwa presentase keberhasilan aktivitas belajar siswa I (pertama) adalah 13 dan pertemua II (kedua) adalah 14. Presentase aktivitas belajar siklus I (satu) dan siklus II (dua) menunjukkan peningkatan maka presentase keberhasilan aktivitas belajar siswa pada siklus II telah berhasil dan sesuai dengan skenario pembelajaran dengan menggunakan metode struktur analitik sintetik (SAS).

Setelah dilaksanakan beberapa kegiatan pembelajaran selama dua siklus, pada tema 6 merawat hewan menurut dan tumbuhan setelah menggunakan metode struktur analitik sintetik (SAS) mengalami sedikit peningkatan sebesar $12,5 \%$ dimana jumlah siswa yang tuntas sebanyak 13 orang dengan persentase ketuntasan klasikal 54,17\% dibandingkan saat peneliti melihat dokumen guru mengenai hasil ulangan harian siswa tahun 2017/2018 hanya 10 orang siswa yang tuntas dengan persentase ketuntasan klasikal 41,67\%.

Setelah dilakukan perbaikan pada siklus II (dua), diadakan evaluasi. Hasil evaluasi siklus II (dua) menunjukkan bahwa rata-rata hasil belajar siswa memperoleh peningkatan sebesar 29,16\% dimana jumlah siswa yang tuntas sebesar 20 orang dengan persentase ketuntasan klasikal 83,33\%. Hal tersebut dapat dilihat pada gambar grafik di bawah ini.

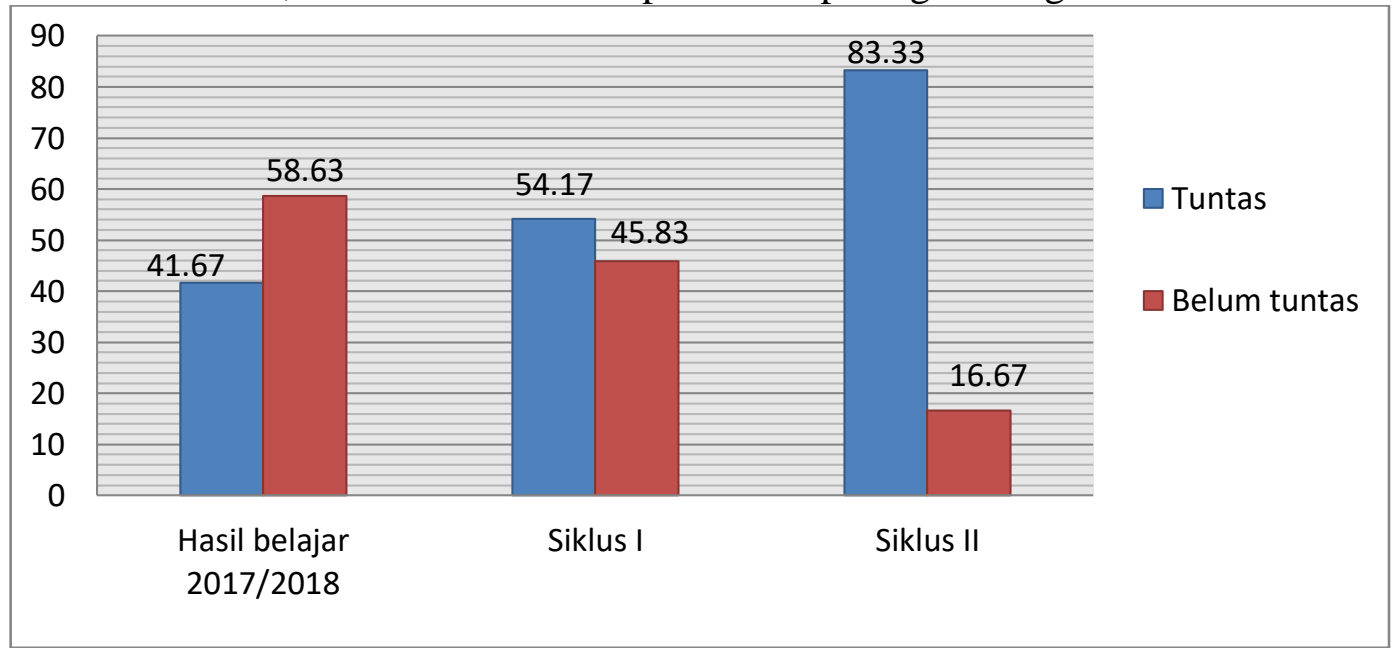

Gambar 1. Perbandingan Hasil Belajar Siswa Siklus I dan Siklus II

Berdasarkan data hasil evaluasi, mulai dari evaluasi siklus I kemudian dilanjutkan evaluasi siklus II, bahwa pembelajaran konvensional yang hanya menggunakan metode ceramah dan pemberian tugas yang dilakukan guru ketika mengajar mendapatkan hasil belajar yang rendah diakibatkan karena siswa merasa bosan dan jenuh dengan cara guru menyampaikan pembelajaran.

Pada saat guru memberikan pembelajaran dengan menggunakan metode struktur analitik sintetik (SAS) siswa menjadi aktif dalam pembelajaran sehingga siswa merasa senang dalam belajar pada materi tema 6 merawat hewan dan tumbuhan.

Penelitian ini dilaksanakan dalam dua siklus dalam dua kali per pembalajaran dengan menggunakan metode struktur analitik sintetik (SAS). Karena pada siklus I guru dan siswa dalam melaksanakan pembelajaran dengan menggunakan metode struktur analitik sintetik (SAS) masih memiliki banyak kekurangan, sehingga hasil belajar yang diperoleh siswa masih 
jauh dari harapan peneliti yang sudah ditetapkan yaitu 80\% (mencapai KKM 70). Pada siklus II guru mengalami peningkatan dalam menggunakan metode struktur analitik sintetik (SAS) dalam proses belajar mengajar, siswa juga dapat memahami apa yang disampaikan oleh guru dan merasa senang dalam belajar. Hasil dari tes yang diperoleh siswa sudah mencapai harapan dari peneliti, sehingga peneliti tidak perlu melanjutkan ke siklus berikutnya.

\section{Simpulan}

Pembelajaran dengan menggunakan metode struktur analitik sintetik dapat meningkatkan hasil belajar kemampuan membaca permulaan siswa kelas II SDN 11 Kendari. Hal tersebut dapat dilihat pada peningkatan hasil belajar siswa pada siklus I (satu) sebesar $54,17 \%$ dibandingkan saat peneliti melihat dokumen guru mengenai hasil ulangan harian siswa tahun 2017/2018 hanya 10 orang siswa yang tuntas dengan persentase ketuntasan klasikal 41,67\%. Akan tetapi, dengan mendapatkan peningkatan pada siklus I (satu), nilai tersebut masih rendah dan belum mencapai harapan dengan ketuntasan yang telah ditetapkan yaitu mencapai $80 \%$. Dengan melihat nilai tersebut maka peneliti melanjutkan penelitian pada siklus II (dua).

Setelah dilakukan perbaikan pada siklus II (dua), maka hasil evaluasi siklus II (dua) menunjukkan bahwa rata-rata hasil belajar siswa memperoleh peningkatan sebesar 29,16\% dimana jumlah siswa yang tuntas sebesar 20 orang dengan persentase ketuntasan klasikal $83,33 \%$.

\section{Referensi}

Aulina, Choirun Nisak. (2012). Pengaruh Permainan Dan Penguasaan Kosakata Terhadap Kemampuan Membaca Permulaan Anak Usia 5-6 Tahun. Pedagogia Vol. 1, No. 2, Juni 2012: 131-143. http://ojs.umsida.ac.id/index.php/pedagogia/article/viewFile/36/42

Dewi, Sri Utami Soraya. (2015). Pengaruh Metode Multisensori Dalam Meningkatkan Kemampuan Membaca Permulaan Pada Anak Kelas Awal Sekolah Dasar. Jurnal Program Studi PGMI. Vol. III, No. 1, Maret 2015. 1-13. http://www.jurnal.stitnualhikmah.ac.id/index.php/modeling/article/view/43

Hendriana, Heris dan Afrilianto. (2017). Langkah Praktis Penelitian Tindakan Kelas Bagi Guru. Bandung: Retika Aditama.

Hidayah, Nurul. (2016). Peningkatkan Kemampuan Membaca Permulaan Dengan Menggunakan Metode Struktur Analitik Sintetik (SAS) Mata Pelajaran Bahasa Indonesia Pada Peserta Didik Kelas II C Semester II Di MIN 6 Bandar Lampung T.A 2015/2016. Terampil Jurnal Pendidikan dan Pembelajaran Dasar Volume 3 $\begin{array}{llllr}\text { Nomor } & 1 & \text { Juni } & 2016 . & 85-102 .\end{array}$ http://103.88.229.8/index.php/terampil/article/view/1331

Kurniawan, Otang \& Noviana Eddy. (2016). Metode Membaca SAS (Struktural Analitik Sintetik) Dalam Meningkatkan Keterampilan Membaca Permulaan Di Kelas I Sdn 79 Pekanbaru. Jurnal Primary Program Studi Pendidikan Guru Sekolah Dasar Fakultas Keguruan dan Ilmu Pendidikan Universitas Riau Volume 5, Nomor 2. 149157. https://primary.ejournal.unri.ac.id/index.php/JPFKIP/article/view/3705 
Paizaluddin dan Ermalinda. (2014). Penelitian Tindakan Kelas (Classroom Action Research). Bandung: Alfabeta

Mayangsari, Dewi. (2014). Peningkatan Kemampuan Membaca Permulaan Kelas 1 SD Mardi Putera Surabaya Dengan Menggunakan PAKEM (Pembelajaran Yang Aktif, Kreatif, Efektif, Dan Menyenangkan). Jurnal Program Studi PGMI. Vol. I, No. 1, Maret 2014. 62-69. http://jurnal.stitnualhikmah.ac.id/index.php/modeling/article/view/35

Mile, Nurnaningsih. (2016). Peningkatan Kemampuan Membaca Permulaan Melalui Pembelajaran Konstruktivisme Dan Penggunaan Papan Flanel di Kelas I SD Negeri 1 Palu. Jurnal Kreatif Tadulako Online Vol. 4 No. 4. 259-268. http://jurnal.untad.ac.id/jurnal/index.php/JKTO/article/view/6123

Rusdiyanto. (2014). Upaya Meningkatkan Keterampilan Membaca Permulaan Melalui Metode Struktural Analitik Sintetik (SAS) Pada Bidang Studi Bahasa Indonesia Siswa Kelas 1 SD Negeri 02 Kunduran Kecamatan Kunduran Kabupaten Blora Tahun Pelajaran 2010/2011. Publikasi Ilmiah. Fakultas Keguruan Dan Ilmu Pendidikan Universitas Sebelas Maret Surakarta. http://eprints.ums.ac.id/30144/13/NASKAH_PUBLIKASI.pdf

Salamah, Siti. (2015). Studi Ringkas Pemerolehan Bahasa Pada Anak. PBSI FKIP Universitas Ahmad Dahlan Yogyakarta. Bahastra Vol 33, No 2 (2015). 73-82. DOI: http://dx.doi.org/10.26555/bahastra.v33i2.2636

Sandi Silvia. (2014). Pengembangan Metode SAS dalam Meningkatkan Keterampilan Membaca Permulaan Siswa, hal. 96-107.

Sumarni, Evi, Rachmat Sahputra, Burhan. (2014). Penerapan Metode Struktural Analitik Sintesis (SAS) Melalui Media Gambar Untuk Meningkatkan Kemampuan Membaca Permulaan Pada Siswa Kelas I Sekolah Dasar. Jurnal Pendidikan Dasar Vol 2, No 1 (2014). Hal. 88-93. DOI: https://doi.org/10.46368/jpd.v2i1.18 